\title{
Microbial bioavailability of dissolved organic carbon from leachates of freshwater autotrophs
}

\author{
Stephen D. Shivers ${ }^{1,2, *}$, Stephen P. Opsahl ${ }^{2,3}$, Alan P. Covich ${ }^{1}$ \\ ${ }^{1}$ Institute of Ecology, Odum School of Ecology, University of Georgia, Athens, GA 30602, USA \\ ${ }^{2}$ Joseph W. Jones Ecological Research Center, 3988 Jones Center Drive, Newton, GA 39870, USA \\ ${ }^{3}$ Present address: USGS Texas Water Science Center, U.S. Geological Survey, 5563 De Zavala Road, Suite 290, \\ San Antonio, TX 78249, USA
}

\begin{abstract}
The concentration and bioavailability of dissolved organic carbon (DOC) released during senescence of aquatic vegetation varies among autotrophs, and the corresponding response by microbial communities depends on DOC bioavailability. To evaluate microbial response to different leachate sources, experiments that measured $\mathrm{O}_{2}$ consumption, utilization of DOC and monosaccharides, and the specific absorbance of light at $350 \mathrm{~nm}$ (SUVA350) were conducted on leachates from 3 primary producers. Specific absorbance at $350 \mathrm{~nm}$ (SUVA350) increased in 2 of 3 experiments. Increases in SUVA350 are consistent with the preferential use of labile DOC with a lower SUVA350. However, similar patterns of monosaccharide and DOC utilization do not support the hypothesis of preferential usage of labile carbohydrates over bulk DOC by the microbial community over the $8 \mathrm{~d}$ study. Monosaccharides appear to represent only a portion of a larger pool of labile DOC constituents that are found in autotrophic leachates that can be taken up more rapidly than metabolized by microbial communities. $\mathrm{O}_{2}$ consumption by the microbial community varied significantly among leachate types but was relatively high during the early phase of the experiments in all leachates. Similarly, DOC uptake was relatively rapid during the early phase of the experiments. The microbial uptake of DOC relative to the consumption of dissolved oxygen, expressed as a ratio, ranged from 2.31 to 3.95 during the initial $24 \mathrm{~h}$ period but approached 1:1 over the duration of the experiment. These ratios suggest that 'luxury uptake' of DOC by microbial communities might have occurred in the initial phase of the experiment.
\end{abstract}

KEY WORDS: Dissolved organic carbon - Bioavailability - Monosaccharides - Leachates · Luxury uptake $\cdot$ Hydrilla verticillata $\cdot$ Potamogeton illinoensis $\cdot$ Lyngbya

\section{INTRODUCTION}

Freshwater ecosystems contribute significantly to the global carbon cycle even though they comprise only a small proportion of the surface of the Earth (Cole et al. 2007). Because of the coupling of inland waters to terrestrial ecosystems, inland waters serve as integrators on a landscape scale and function as sentinels for a changing climate (Williamson et al. 2008, Schindler 2009). Inland waters store carbon through burial in the sediment and help regulate biogeochemical cycling on a global scale (Tranvik et al. 2009).

${ }^{*}$ Corresponding author: sshivers@jonesctr.org
One of the principal methods for the regulation of nutrient cycling is the uptake and release of nutrients by aquatic vegetation (Flindt et al. 1999). Aquatic vegetation affects an array of physical and chemical characteristics in the water in which it grows (Carpenter \& Lodge 1986). These effects include changes in light penetration, water flow, and nutrient cycling (Madsen et al. 2001, Havens 2003) and can be strong enough to regulate water clarity on a lake-wide scale (Scheffer et al. 1993). One of the ways in which these effects are produced is through the leaching of nutrients from plants, and this leaching occurs while

() The authors 2016. Open Access under Creative Commons by Attribution Licence. Use, distribution and reproduction are unrestricted. Authors and original publication must be credited. 
plants are alive and during senescence and death (Godshalk \& Wetzel 1978, Barko et al. 1986, Mann \& Wetzel 1996).

Plant leachates are utilized by bacteria and are crucial for nutrient cycling because they make nutrients and dissolved organic carbon (DOC) available to higher trophic levels by incorporating these elements into their biomass, which may then be consumed by herbivores and omnivores (Benner et al. 1986, Findlay et al. 1986). Microbial utilization of leached material can be fast and can yield a high bacterial growth efficiency (Ogawa et al. 2001). Plant leachates can differ greatly in chemical composition, and this, in turn, can cause the leachate to function differently (Opsahl \& Benner

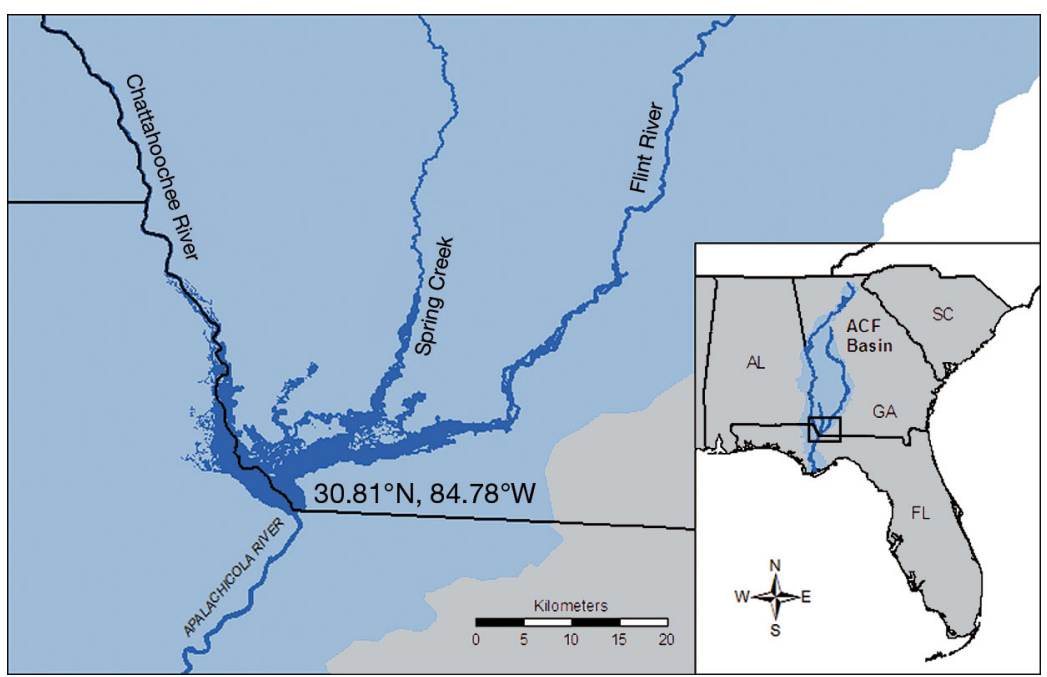

Fig. 1. Location of Lake Seminole in southwestern Georgia, USA, showing inflows from the Chattahoochee River, Flint River, and Spring Creek, and outflow to the Apalachicola River. ACF Basin: Apalachicola-Chattahoochee-Flint Basin
1999, Stepanauskas et al. 2000, Maie et al. 2006). The purpose of this study was to determine the concentration of nutrients $\left(\mathrm{NO}_{3}, \mathrm{NH}_{4}\right.$, and $\left.\mathrm{PO}_{4}\right)$ and DOC released through leaching from different types of autotrophs, and to assess the bioavailability of DOC to microbial communities in a series of experiments in which natural microbial communities were exposed to leachates from the different sources. Other studies have assessed the effects that submerged aquatic vegetation, such as Hydrilla verticillata, can have on nutrient concentration and availability, but few have directly assessed the bioavailability of carbon to the microbial community (Barko et al. 1988, Takamura et al. 2003, Gu 2006). Monosaccharide utilization rates were measured because monosaccharides are thought to be a relatively labile form of DOC that can help to explain the differences in microbial metabolism of specific compound classes.

\section{MATERIALS AND METHODS}

\section{Site description}

Lake Seminole is a 15216 ha impoundment located in southwestern Georgia, USA, within the Apalachicola-Chattahoochee-Flint Basin (Fig. 1). The mean depth of Lake Seminole is $3 \mathrm{~m}$ and the maximum depth is $10.7 \mathrm{~m}$ (Sammons et al. 2005, McEntire 2009). The major surface inflows into Lake Seminole are the Chattahoochee River, the Flint River, and Spring Creek. These tributaries drain a combined land area of $46141 \mathrm{~km}^{2}$. Groundwater also contributes a substantial component of flow into the lake (Torak et al. 2006). Concentrations of nutrients within the lake were measured monthly over a 12 mo period during a study by McEntire (2009). Submerged aquatic vegetation has historically covered large areas of the major inflows of Lake Seminole: $46 \%$ of the Chattahoochee River, $38 \%$ of the Flint River, and $89 \%$ of Spring Creek in a 1997 survey by the USACE (Brown \& Maceina 2002).

\section{Plant collection and leaching}

Plant material was collected in Lake Seminole near the mouth of Spring Creek (Fig. 1). Living biomass was collected during October 2009 from Lake Seminole for the following autotrophs: hydrilla Hydrilla verticillata, Illinois pondweed Potamogeton illinoensis, and the cyanobacterial mat-forming Lyngbya spp. The plants were transported on ice to the Joseph W. Jones Ecological Research Center, where they were washed with deionized water, weighed, and placed in a drying oven at $45^{\circ} \mathrm{C}$. The samples were dried for at least $48 \mathrm{~h}$ before dry weights were recorded.

Dried plant material (5 g) was placed in 11 glass beakers to which $900 \mathrm{ml}$ of ultrapure $\mathrm{H}_{2} \mathrm{O}$ were added. The beakers were covered and refrigerated between 0 and $5^{\circ} \mathrm{C}$ in the dark for $14 \mathrm{~d}$. The plant material was then removed from the beakers and returned to the drying oven to be weighed after drying. The leachate was filtered through a $0.22 \mu \mathrm{m}$ nitrocellulose filter to remove most bacteria and stored in 11 Nalgene polycarbonate bottles below $0^{\circ} \mathrm{C}$. 


\section{Incubations with leachates}

Incubations to assess the bioavailability of carbon from the different leachates were performed using biological oxygen demand (BOD) bottle experiments. Water collected from Lake Seminole was filtered through a pre-ashed $0.7 \mu \mathrm{m}$ filter to remove particulate matter and retain most of the microbial community. Filtered water $(6 \mathrm{ml})$ was then added to BOD bottles to serve as a microbial inoculum. Plant leachate was added so that the DOC concentration was approximately $250 \mu \mathrm{M}$. Based on previous analysis of the different leachates, nutrient amendments were added in excess $\left(0.06 \mathrm{M} \mathrm{NH}_{4} \mathrm{Cl}, 0.06 \mathrm{M}\right.$ $\mathrm{C}_{6} \mathrm{H}_{12} \mathrm{O}_{6}, 0.06 \mathrm{M} \mathrm{Na}_{2} \mathrm{HPO}_{4} \cdot 5 \mathrm{H}_{2} \mathrm{O}$, and $0.06 \mathrm{M} \mathrm{NaNO}_{3}$ ) to maintain equivalent nutrient concentrations among treatments caused by the differences in plant leachate composition. It is important to note that inorganic nutrient ratios can also alter respiratory quotients (RQs) (Cimbleris \& Kalff 1998); however, nutrient amendments were added in order to focus on changes caused by differences in carbon quality. Beginning the experimental incubations with equivalent inorganic nutrient concentrations in excess enabled us to focus solely on carbon utilization without interference caused by inorganic nutrient differences. The remainder of the bottle was filled with artificial lake water (Smart \& Barko 1985). All bottles were incubated in the dark for $168 \mathrm{~h}(7 \mathrm{~d})$ at $27.5^{\circ} \mathrm{C}$. Two controls were also included in this experiment: (1) $100 \%$ lake water; (2) 6 ml lake water, nutrient amendments, and the remainder artificial lake water. DOC and monosaccharide concentrations were measured in triplicate, and $\mathrm{O}_{2}$ consumption was measured in duplicate. Every $24 \mathrm{~h}, 1$ set of 3 bottles was removed and refrigerated below $5^{\circ} \mathrm{C}$ to stop microbial activity. After 168 h, contents of the bottles were filtered through $0.22 \mu \mathrm{m}$ pre-ashed glass fiber filters to remove microbes. Samples were stored at 0 to $5^{\circ} \mathrm{C}$ for $\mathrm{DOC}$ and below $0^{\circ} \mathrm{C}$ for monosaccharides until analysis. Additionally, during the experiment, 2 bottles were removed every $24 \mathrm{~h}$ and fixed with $\mathrm{NaI} / \mathrm{NaOH}$ and $\mathrm{MnSO}_{4}$ for Winkler titrations (Opsahl 2005).

\section{Sample and statistical analyses: CHN, DOC, monosaccharides, and bioassays}

CHN analysis was performed on a Thermo Scientific Flash 2000 elemental analyzer. Dried plant material was ground using a Spex ball mill grinder prior to analysis. The organic carbon (OC) composition of acidified samples was determined using the method of Hedges \& Stern (1984). A mass balance approach was used to evaluate whether large losses of OC occurred during leachate preparation due to microbial uptake. Initial $\mathrm{OC}$ in the incubations was calculated by multiplying the initial dry weight by the initial \%OC. Likewise, the final OC present in the incubation was calculated by multiplying the final dry weight by the final \% OC. Percent recovery was calculated by dividing the initial OC by the sum of the final OC and DOC of the leachate.

DOC was measured using a Shimadzu TOC-V total carbon analyzer. Dissolved monosaccharides were measured using the 2,4,6-tripyridyl-s-triazine (TPTZ) colorimetric Myklestad method as modified by Hung \& Santschi (2001). Measurements of absorbance at $595 \mathrm{~nm}$ for the TPTZ method were made using a Shimadzu UV-2101 spectrophotometer. Filtered water samples were also analyzed for their UV/vis absorbance spectra (280-800 nm) using the Shimadzu spectrophotometer. Specific absorbance at $350 \mathrm{~nm}$ (SUVA350) was calculated by dividing the absorbance at $350 \mathrm{~nm}$ by the concentration of DOC. Dissolved oxygen concentrations were determined through titration utilizing the Winkler method and a Mettler Toledo DL50 titrator (Pomeroy et al. 1994, Opsahl 2005). Graphic visualization of data was achieved by using Igor Pro 6.2. Analysis of variance (ANOVA) with a post hoc Tukey's HSD test was executed on the data using the statistical packages of $\mathrm{R}$ (R ver. 2.12.0).

\section{RESULTS}

Hydrilla verticillata plant tissue was initially composed of $25.3 \%$ OC and was composed of $34.0 \%$ OC after incubation (Table 1). Potamogeton illinoensis tissue contained higher levels of OC initially (38.2\%) and after incubation (41.3\%). Lyngbya spp. tissue had an initial composition of $38.2 \%$ OC and a final composition of $36.6 \%$ OC. The percent recoveries of

Table 1. Organic carbon $(\mathrm{OC})$ content $( \pm \mathrm{SD})$ and \% recovery of OC before and after leaching experiments for different autotrophs

\begin{tabular}{|lccc|}
\hline & Initial \% OC & Final \% OC & \% Recovery \\
\hline Potamogeton illinoensis & $38.2 \pm 0.05$ & $41.3 \pm 0.03$ & 104.8 \\
Hydrilla verticillata & $25.3 \pm 0.38$ & $34.0 \pm 0.02$ & 117.3 \\
Lyngbya spp. & $38.2 \pm 0.16$ & $36.6 \pm 0.08$ & 101.9 \\
\hline
\end{tabular}


OC in the $H$. verticillata, $P$. illinoensis, and Lyngbya spp. incubations were 117.3, 104.8, and 101.9\%, respectively, indicating that substantial amounts of OC were not lost to microbial uptake during the leachate extraction.

Nutrient concentrations varied significantly among the different plant types (Table 2 ). $H$. verticillata leachate had the lowest concentration of DOC $(1.43 \times$ $\left.10^{4} \mu \mathrm{M}\right)$ and the highest concentrations of $\mathrm{PO}_{4}$ $(155.8 \mu \mathrm{M})$ and $\mathrm{NO}_{3}(4.7 \mu \mathrm{M})$. Lyngbya spp. leachate had the highest $\mathrm{NH}_{4}$ and DOC concentrations (1.01 $\times$ $10^{3} \mu \mathrm{M}$ and $3.62 \times 10^{4} \mu \mathrm{M}$, respectively) and the lowest $\mathrm{PO}_{4}$ and $\mathrm{NO}_{3}$ concentrations $(3.4 \mu \mathrm{M}$ and $0.5 \mu \mathrm{M}$, respectively). $P$. illinoensis leachate was intermediate for all nutrient concentrations except $\mathrm{NH}_{4}$, which was the lowest of the 3 autotrophs.

Overall, the DOC concentrations varied significantly over time among the different leachate treatments (ANOVA, $\mathrm{p}<0.01$; Fig. 2). The DOC concentration of BOD bottles containing $H$. verticillata leachate dropped sharply during the first $24 \mathrm{~h}$ (from

Table 2. Nutrient and dissolved organic carbon (DOC) concentrations for different autotrophs and the natural range of Lake Seminole (Georgia, USA)

\begin{tabular}{|lcccc|}
\hline & $\mathrm{DOC}(\mu \mathrm{M})$ & $\mathrm{NH}_{4}(\mu \mathrm{M})$ & $\mathrm{PO}_{4}(\mu \mathrm{M})$ & $\mathrm{NO}_{3}(\mu \mathrm{M})$ \\
\hline Potamogeton illinoensis & $2.66 \times 10^{4}$ & 171.3 & 55.7 & 2.3 \\
Hydrilla verticillata & $1.43 \times 10^{4}$ & 720.7 & 155.8 & 4.7 \\
Lyngbya spp. & $3.62 \times 10^{4}$ & $1.01 \times 10^{3}$ & 3.4 & 0.5 \\
Lake range & $25-899.2$ & $0-6.04$ & $0-0.4$ & $1.5-34.5$ \\
\hline
\end{tabular}

252.3 to $119.9 \mu \mathrm{M}$ ) and decreased at a slower rate for the next $144 \mathrm{~h}$ (from 119.9 to $62.4 \mu \mathrm{M}$ ). Bottles containing Lyngbya spp. leachate also exhibited sharply decreasing DOC concentrations during the first $24 \mathrm{~h}$ (from 213.1 to $58.3 \mu \mathrm{M}$ ), but DOC decreased at a slower rate for the next $144 \mathrm{~h}$ (from 58.3 to $25.8 \mu \mathrm{M}$ ). DOC concentrations for $P$. illinoensis bottles decreased less sharply than for $H$. verticillata or Lyngbya spp. for the first $24 \mathrm{~h}$ (from 230.6 to $156.5 \mu \mathrm{M}$ ), and they continued to decrease over the next $144 \mathrm{~h}$ (from 156.5 to $108.2 \mu \mathrm{M}$ ). For the lake water without added leachate, DOC decreased slightly over the duration of the experiment (from 215.6 to $190.7 \mu \mathrm{M}$ ). The samples composed of a mixture of artificial lake water and $10 \%$ lake water decreased by $3.3 \mu \mathrm{M}$ over the first $24 \mathrm{~h}$, and DOC concentrations were $\sim 0 \mu \mathrm{M}$ for the remainder of the experiment.

Monosaccharide concentrations varied significantly over time based upon leachate type (ANOVA, p < 0.01). Monosaccharide concentrations of all leachates decreased similarly over the first $24 \mathrm{~h}\left(1.7 \mu \mathrm{M} \mathrm{h}^{-1}\right)$ and for the remainder of the experiment (Table 3, Fig. 3). Values of the $100 \%$ lake water samples were significantly higher $(40.0 \mu \mathrm{M})$ than those of the artificial lake water samples $(5.0 \mu \mathrm{M})$ due to the presence of monosaccharides within the lake. Neither control group experienced significant concentration changes over the course of the experiment.

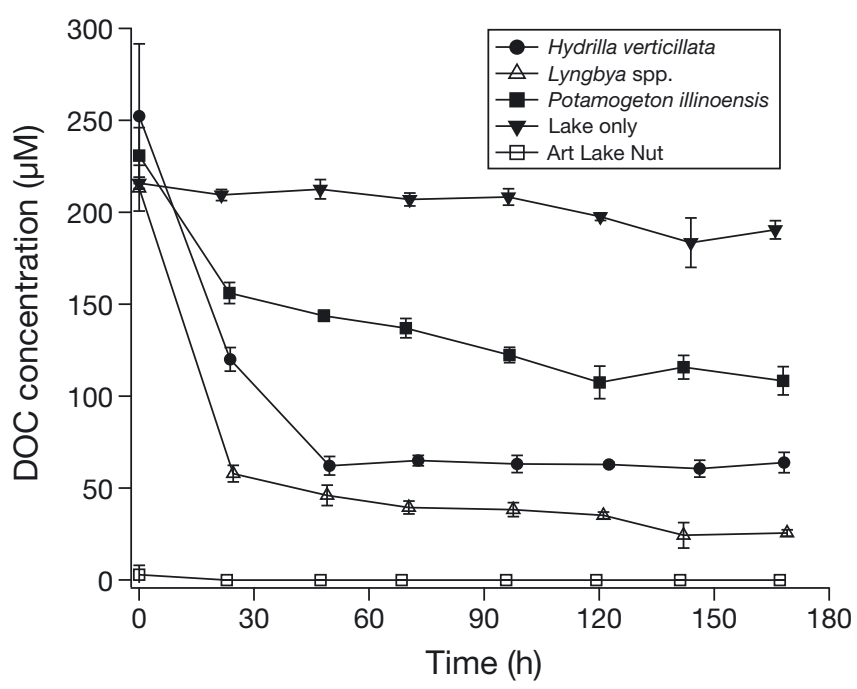

Fig. 2. Dissolved organic carbon (DOC) concentrations measured during incubations of leachates from 3 autotrophs and 2 lake water controls (Lake only: $100 \%$ lake water; Art Lake Nut: lake water + nutrient amendments + artificial lake water; see 'Materials and methods; Incubations with leachates' for details)

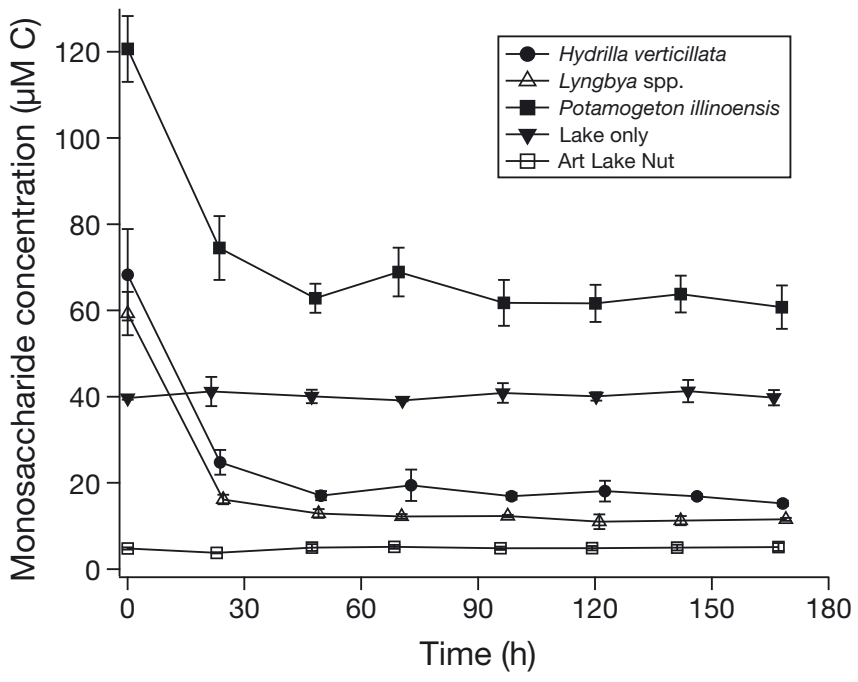

Fig. 3. Monosaccharide concentrations measured during incubations of leachates from 3 autotrophs and 2 lake water controls (Lake only: 100\% lake water; Art Lake Nut: lake water + nutrient amendments + artificial lake water; see 'Materials and methods; Incubations with leachates' for details) 
Table 3. Dissolved organic carbon (DOC) and monosaccharide loss rates $\left(\mathrm{g} \mathrm{C}^{-1} \mathrm{~h}^{-1}\right)$ during the first $24 \mathrm{~h}(\mathrm{~T} 0-\mathrm{T} 1)$ and for the following $144 \mathrm{~h}(\mathrm{~T} 1-\mathrm{TF})$

\begin{tabular}{|lcccc|}
\hline & \multicolumn{2}{c}{ DOC } & \multicolumn{2}{c|}{$\begin{array}{c}\text { Monosaccharides } \\
\end{array}$} \\
& T0-T1 & T1-TF & T0-T1 & T1-TF \\
\hline Potamogeton illinoensis & 0.037 & 0.004 & 0.023 & 0.0011 \\
Hydrilla verticillata & 0.066 & 0.005 & 0.022 & 0.0008 \\
Lyngbya spp. & 0.078 & 0.003 & 0.022 & 0.0004 \\
Lake only & 0.003 & 0.002 & 0 & 0.0001 \\
\hline
\end{tabular}

Total $\mathrm{O}_{2}$ consumption was greatest in $H$. verticillata leachates. These bottles lost $57.3 \mu \mathrm{M}$ of $\mathrm{O}_{2}$ during the first $24 \mathrm{~h}$ and $189.6 \mu \mathrm{M}$ of $\mathrm{O}_{2}$ over $168 \mathrm{~h}$ (Fig. 4). Lyngbya spp. leachate had a more rapid loss during the first $24 \mathrm{~h}\left(62.8 \mu \mathrm{M}\right.$ of $\mathrm{O}_{2}$ lost $)$, but slowed considerably thereafter (152.7 $\mu \mathrm{M}$ total $\mathrm{O}_{2}$ decrease). P. illinoensis leachate had the slowest $\mathrm{O}_{2}$ consumption in the first $24 \mathrm{~h}\left(18.9 \mu \mathrm{M} \mathrm{O}_{2}\right)$ and the slowest overall $\mathrm{O}_{2}$ consumption $\left(106.8 \mu \mathrm{M} \mathrm{O}_{2}\right)$ among the 3 plant types. The $\mathrm{O}_{2}$ consumption rates of both controls were low, but steady for the duration of the experiment.

SUVA350 varied among the samples. P. illinoensis leachate increased from 2.86 to 5.32 and Lyngbya spp. leachate increased from 0.72 to 2.72 (Fig. 5). In contrast, $H$. verticillata leachate remained fairly constant throughout the experiment with a mean of 2.01. The lake water control also remained constant during the experiment.

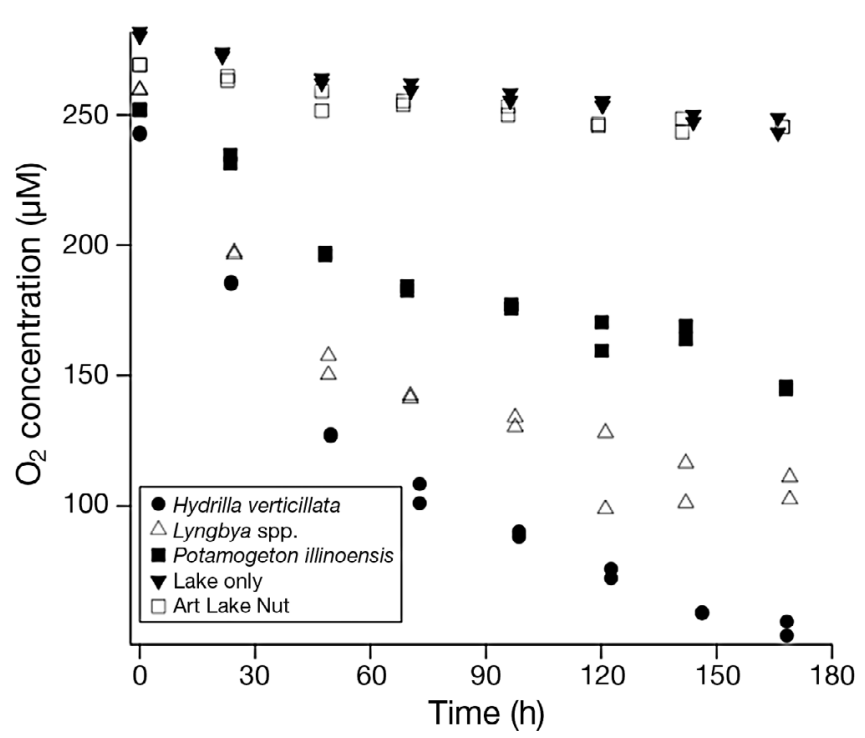

Fig. 4. $\mathrm{O}_{2}$ concentrations measured during incubations of leachates from 3 autotrophs and 2 lake water controls (Lake only: $100 \%$ lake water; Art Lake Nut: lake water + nutrient amendments + artificial lake water; see 'Materials and methods; Incubations with leachates' for details)
The microbial uptake of DOC relative to the microbial consumption of dissolved oxygen (DOC: $\left.\mathrm{O}_{2}\right)$ was calculated over the first $24 \mathrm{~h}$ and for the duration of the experiment using the following formulae: $\left(\mathrm{DOC}_{\mathrm{T}}\right.$ - $\left.\mathrm{DOC}_{\mathrm{T} 1}\right) /\left(\mathrm{DO}_{\mathrm{T} 0}-\mathrm{DO}_{\mathrm{T} 1}\right)$ and $\left(\mathrm{DOC}_{\mathrm{T} 0}-\mathrm{DOC}_{\mathrm{TF}}\right) /$ $\left(\mathrm{DO}_{\mathrm{T} 0}-\mathrm{DO}_{\mathrm{TF}}\right)$, respectively, where $\mathrm{T} 0=$ concentration at the beginning of the experiment, $\mathrm{T} 1=$ concentration at the first time point $(24 \mathrm{~h})$, and $\mathrm{TF}=$ concentration at the conclusion of the experiment (168 h). During the first $24 \mathrm{~h}, \mathrm{DOC}: \mathrm{O}_{2}$ ratios were higher than 1:1 for the plant leachates (Fig. 6). These ratios varied from 2.31:1 for $H$. verticillata to 3.95:1 for $P$. illinoensis. The ratio of oxygen consumed to DOC consumed was approximately 1:1 over the duration of the experiment for all leachates and lake water.

\section{DISCUSSION}

\section{OC utilization and bioavailability}

Overall DOC utilization and oxygen consumption varied significantly among autotrophs, which implies differences in bioavailability to microbial communities (Figs. 2 \& 4). Hydrilla verticillata leachate exhibited the largest decreases in $\mathrm{O}_{2}$ concentrations. A combination of sharp decreases of DOC and monosaccharides along with increased $\mathrm{O}_{2}$ consumption suggests that $H$. verticillata leachates contained more bioavailable carbon than the other autotrophs. SUVA350 values did not show a net increase over time (Fig. 5) as observed for Lyngbya spp. and Pota-

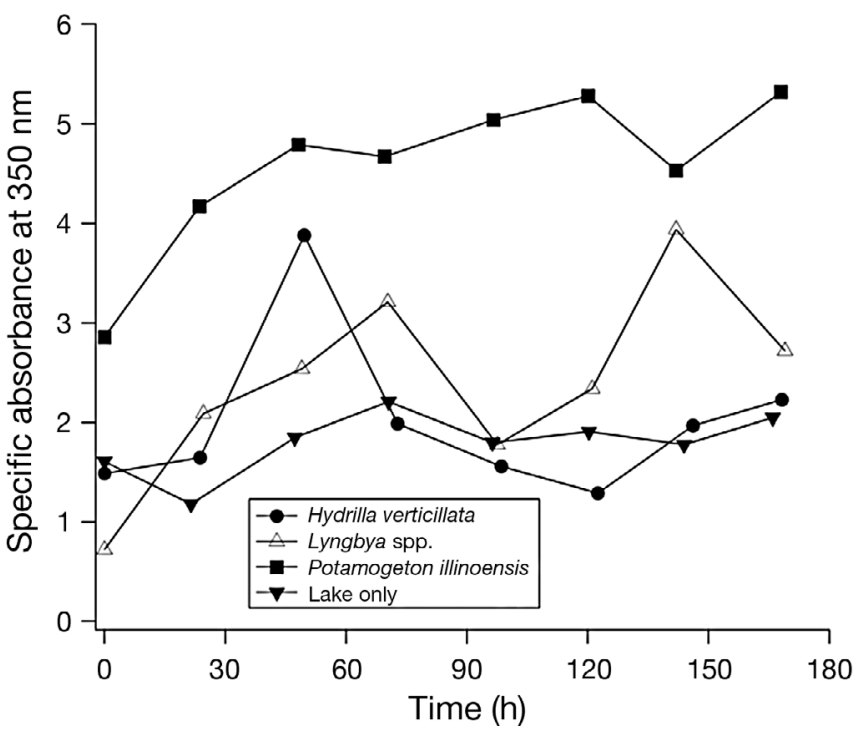

Fig. 5. Specific absorbance at $350 \mathrm{~nm}$ measured during incubations of leachates from 3 autotrophs and lake water only control 


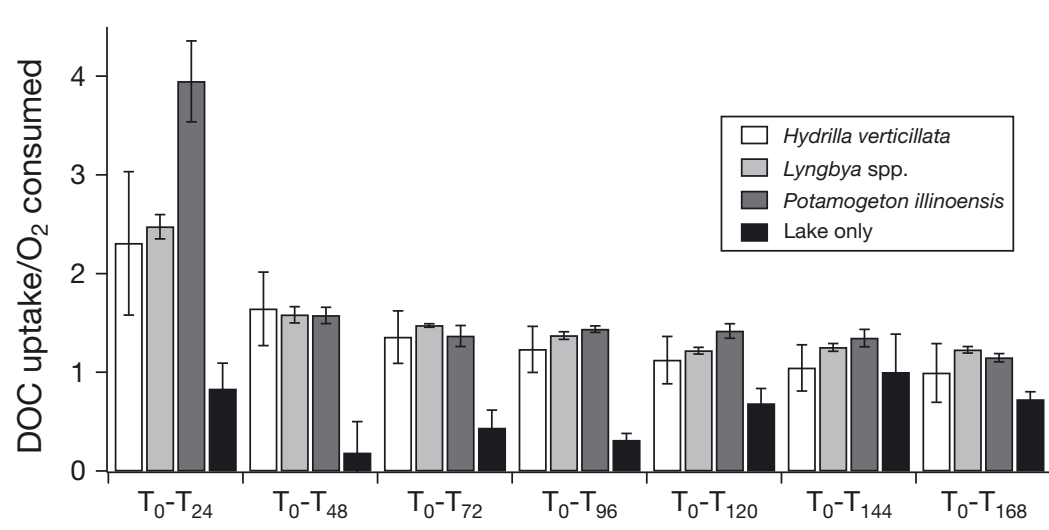

Fig. 6. Microbial uptake of dissolved organic carbon (DOC) relative to the microbial consumption of dissolved oxygen (DOC: $\mathrm{O}_{2}$ ) increasing by $24 \mathrm{~h}$ intervals starting at time 0 and continuing through $168 \mathrm{~h}$

These results indicate that there was a small quantity of immediately bioavailable carbon, and very little became available after the initial loss. This is supported by the lowest overall $\mathrm{O}_{2}$ consumption rates. The structural nature of this plant could be responsible for these rates. Notably, these experiments were performed in the absence of light. Were sunlight to be included, $P$. illinoensis DOC utilization rates would likely have been enhanced because of the susceptibility of aromatic DOC to UV oxidation, which has been shown to produce highly labile DOC from biologically refractory parent molecules (Amon \& Benner 1996).

mogeton illinoensis, which implies that refractory bulk DOC was not enriched during the experiment and further supports the greater bioavailability of carbon from $H$. verticillata. The results demonstrate that $H$. verticillata has the potential to indirectly affect nutrient cycling in Lake Seminole by causing changes in microbial metabolism, and these changes would occur on a larger scale because of the potential for high spatial coverage by this autotroph.

Lyngbya spp. leachate had the fastest $\mathrm{O}_{2}$ consumption rates during the first $24 \mathrm{~h}$, followed by decreased $\mathrm{O}_{2}$ consumption thereafter (Fig. 4). Lyngbya species found in marine systems are prolific producers of secondary metabolites and other organic compounds (Nunnery et al. 2010). The patterns of DOC and monosaccharide utilization rates by Lyngbya spp. (Figs. 2 \& 3) imply that labile carbon was present initially and was quickly taken up by microbes. These results support and further explain a previous study which demonstrated a positive correlation between cyanobacterial density and the microbial response to DOC from the cyanobacteria (Wang \& Priscu 1994). Considering the rapid use of labile carbon and other organic compounds from Lyngbya spp. and that cyanobacterial blooms could possibly be more frequent as a result of climate change (Paerl \& Huisman 2009), the potential effects of Lyngbya spp. on nutrient cycling observed in this study should be considered in reservoirs and lakes undergoing similar shifts in microbial community structure.

$P$. illinoensis incubations had the lowest rates of carbon and $\mathrm{O}_{2}$ consumption (Figs. 2 \& 4). The first $24 \mathrm{~h}$ were the slowest of all samples for DOC utilization, although the pattern of monosaccharide usage was comparable to the other samples. Both DOC and monosaccharide utilization rates were low after the first $24 \mathrm{~h}$.
Qualitatively, the leachates in this experiment were quite different and ranged in color from clear with a bluish tint (Lyngbya spp.) to dark tea-colored $(P$. illinoensis). This coloration implies that these leachates are optically different and that, as a result, they could have different degrees of reactivity (Kowalczuk et al. 2003, Boyd \& Osburn 2004, Coble 2007). P. illinoensis is characterized by long stems that have fewer leaves than other submerged vegetation. It is likely that more structural components, such as aromatic rings, are present in these leachates than in the others. The initially high SUVA350 (Fig. 5) and stained, tea-like appearance of this leachate provides evidence for a larger aromatic component, which may explain the observed slower rates of metabolism.

There were also striking similarities among autotrophs with regard to monosaccharide uptake during the first $24 \mathrm{~h}$ as evidenced by comparable rates of monosaccharide loss (Table 3). These loss rates demonstrate that monosaccharides were readily available to the microbial community. Loss rate patterns for DOC in the initial $24 \mathrm{~h}$ were also similar for all autotrophs, indicating that a portion of the bulk DOC was available. However, $P$. illinoensis loss rates were lower than those of the other autotrophs. The structural nature of $P$. illinoensis might require further conditioning to make the DOC more available for use, i.e. increased UV photooxidation. In addition to $P$. illinoensis leachate, all leachates and the lake water control had a portion of the monosaccharides that were not used by the microbial community. It is possible that the structural composition of these monosaccharides prevented uptake and utilization.

We found that the $\mathrm{DOC}: \mathrm{O}_{2}$ ratios for all plant leachates for the first time period were greater than 2:1 while remaining near 1:1 for the overall experi- 
ment (Fig. 6). The initially elevated DOC: $\mathrm{O}_{2}$ ratios suggest that more $\mathrm{OC}$ is being taken up by microbes than is being concurrently respired and may represent 'luxury uptake' by the microbial community. This concept of luxury uptake of carbon has been reported for bacteria in marine systems (Kuipers et al. 2000) but not in freshwater systems. A separate component of our project (Shivers 2010) demonstrated OC limitations in the microbial communities present in the study area by measuring $\mathrm{O}_{2}$ consumption after adding a series of nutrients and a source of labile carbon in bioassay experiments. Similar carbon limitation has also been demonstrated in marine systems (Carlson \& Ducklow 1996). Luxury uptake is a plausible mechanism to provide microbial communities the ability to rapidly take up dissolved OC that may be the primary substrate limiting growth.

Previous studies have demonstrated that bacteria store carbon as reserve energy sources through the synthesis of storage molecules, such as polysaccharides and lipids, particularly through the synthesis of polyhydroxyalkanoates (PHAs) (Wilkinson 1963, Anderson \& Dawes 1990). Poly(3-hydroxybutyrate) is one of the most abundant and well-studied PHAs and has been found in a variety of bacterial species. It is possible that the storage molecules were synthesized from the excess DOC uptake and stored for future use, supporting the concept of luxury uptake in the presence of labile DOC. Alternatively, it is possible that the microbial populations immediately metabolized the labile DOC and increased the total microbial biomass and thus the total particulate OC fraction in the experiment. Neither specific metabolites, such as PHAs, nor estimates of microbial biomass were included in this study, and the relative roles that these processes may play in explaining the early rapid uptake of DOC are as yet unknown. The focus of this study was on DOC, and other fractions of carbon were unfortunately not analyzed; thus, elucidating the exact mechanism falls outside the scope of this study.

An alternative explanation for the differences in DOC: $\mathrm{O}_{2}$ ratios is preferential metabolism of more oxidized constituents which could also explain increases in these ratios. Studies have demonstrated that leachate and exudates from $H$. verticillata contain organic acids, such as caffeic acid ester and other phenolic compounds (Glomski et al. 2002, Gao et al. 2011, Wang et al. 2015). These compounds have been shown to increase RQs as the microbial community preferentially uses organic acids instead of more reduced substrates (Berggren et al. 2012). It is likely that freshwater Lyngbya species also produce an array of organic compounds that could be used preferentially by the microbial community producing a greater RQ. Wang et al. (2010) found that extracts of 2 Potamogeton species contained strong, polar organic acids that were mostly different than those found in $H$. verticillata. These extracts contained palmitic acid, which has been shown to lower the RQ to $<1$.

In order for the changes in RQs to account for the elevated DOC: $\mathrm{O}_{2}$ ratios, the leachates would need to consist of a large proportion of reduced constituents. As indicated above, prior studies have indicated that reduced compounds are present within these plant leachates, but it is not clear whether the proportions are high enough to drive changes in RQs. The leachates used in this study were shown to contain high proportions of monosaccharides, consistent with the results of Hung et al. (2005) in a freshwater system in Texas, USA. Metabolism of carbohydrates would be expected to have an RQ close to 1 and argues in favor of the possibility that the increased DOC: $\mathrm{O}_{2}$ resulted from luxury uptake. However, it is also possible that the remaining labile DOC contains a substantial proportion of more reduced compounds and RQs are considerably different during the rapid metabolism of labile DOC derived from plant leachates. A comprehensive characterization of labile DOC at the molecular level would resolve these possibilities, but, to date, only a small portion of the total DOC in leachates has been characterized at the molecular level (Maie et al. 2006).

\section{Nutrient composition of leachates}

Differing plant types can have very different biochemical compositions, which can affect what is leached upon senescence; these differences, in turn, can affect local nutrient cycling (Hooper \& Vitousek 1998). Quantitatively, the nutrient compositions of the leachates were variable, although all concentrations were significantly higher than ambient concentrations within the lake. This variation could be expected considering the different physiologies of these macrophytes. The different nutrient compositions and when those nutrients are released can have an impact on nutrient cycling in the surrounding waters (Carpenter 1980, Carpenter \& Lodge 1986). Because $H$. verticillata can cover large spatial areas and has the potential to leach high concentrations of $\mathrm{NO}_{3}(4.7 \mu \mathrm{M}), \mathrm{PO}_{4}(155.8 \mu \mathrm{M})$, and $\mathrm{NH}_{4}(720.7 \mu \mathrm{M})$, this influx of nutrients upon senescence could affect nutrient cycling on large scales. Nutrients can also be 
moved throughout the water body by non-rooted species, such as Lyngbya spp. Lyngbya spp. releases high concentrations of $\mathrm{NH}_{4}\left(1.01 \times 10^{3} \mu \mathrm{M}\right)$ upon senescence and could be responsible for nitrogen transport throughout a water body. Additionally, Lyngbya spp. can fix nitrogen under anaerobic conditions in the benthos (Phlips et al. 1992). Therefore, the nutrient composition of primary producers can affect shallow areas where macrophytes are more abundant, but also cycling throughout the lake.

The availability of labile carbon is important because it serves as an energy source for the microbial community. Our study provides evidence that autotrophs release a different quantity and quality of labile carbon upon senescence and that microbial communities can respond to these differences. One possibility is that luxury uptake of labile carbon is occurring and serves as an effective mechanism for microbial communities to respond to the release of this substrate by autotrophs. In addition to a large proportion of labile monosaccharides, labile DOC contains an abundance of as yet unidentified compounds. Labile carbon sources increase microbial metabolism, which directly impacts nutrient cycling within aquatic systems. Understanding differences in bioavailability of carbon is therefore crucial to understanding nutrient cycling in aquatic ecosystems.

Acknowledgements. We thank Bryan Cloninger, Brian Clayton, and Stephanie Allums for assistance in the field and the laboratory. We also thank Jean Brock for assistance with ArcGIS. We appreciate the helpful comments by 3 anonymous reviewers that improved this manuscript. Funding for this project was provided by the Joseph W. Jones Ecological Research Center and the University of Georgia Graduate School.

\section{LITERATURE CITED}

Amon RMW, Benner R (1996) Photochemical and microbial consumption of dissolved organic carbon in the Amazon River. Geochim Cosmochim Acta 60:1783-1792

> Anderson AJ, Dawes EA (1990) Occurrence, metabolism, metabolic role and industrial uses of bacterial polyhydroxyalkanoates. Microbiol Rev 54:450-472

Barko JW, Adams MS, Clesceri NL (1986) Environmental factors and their consideration in the management of submersed aquatic vegetation: a review. J Aquat Plant Manag 24:1-10

Barko JW, Smart RM, McFarland DG, Chen RL (1988) Interrelationships between the growth of Hydrilla verticillata (L. f.) Royle and sediment nutrient availability. Aquat Bot 32:205-216

Benner R, Peele ER, Hodson RE (1986) Microbial utilization of dissolved organic matter from leaves of the red mangrove, Rhizophora mangle, in the Fresh Creek estuary, Bahamas. Estuar Coast Shelf Sci 23:607-619
Berggren M, Lapierre LF, del Giorgio PA (2012) Magnitude and regulation of bacterioplankton respiratory quotient across freshwater environmental gradients. ISME $\mathrm{J}$ 6: 984-993

> Boyd TJ, Osburn CL (2004) Changes in CDOM fluorescence from allochthonous and autochthonous sources during tidal mixing and bacterial degradation in two coastal estuaries. Mar Chem 89:189-210

Brown SJ, Maceina MJ (2002) The influence of disparate levels of submersed aquatic vegetation on largemouth bass population characteristics in a Georgia reservoir. J Aquat Plant Manag 40:28-35

Carlson CA, Ducklow HW (1996) Growth of bacterioplankton and consumption of dissolved organic carbon in the Sargasso Sea. Aquat Microb Ecol 10:69-85

Carpenter SR (1980) Enrichment of Lake Wingra, Wisconsin, by submersed macrophyte decay. Ecology 61:1145-1155 Carpenter SR, Lodge DM (1986) Effects of submersed macrophytes on ecosystem processes. Aquat Bot 26:341-370

Cimbleris ACP, Kalff J (1998) Planktonic bacterial respiration as a function of $\mathrm{C}: \mathrm{N}: \mathrm{P}$ ratios across temperate lakes. Hydrobiologia 384:89-100

Coble PG (2007) Marine optical biogeochemistry: the chemistry of ocean color. Chem Rev 107:402-418

Cole JJ, Prairie YT, Caraco NF, McDowell WH and others (2007) Plumbing the global carbon cycle: integrating inland waters into the terrestrial carbon budget. Ecosystems 10:172-185

Findlay S, Carlough L, Crocker MT, Gill HK, Meyer JL, Smith PJ (1986) Bacterial growth on macrophyte leachate and fate of bacterial production. Limnol Oceanogr 31: 1335-1341

> Flindt MR, Pardal MA, Lillebø AI, Martins I, Marques JC (1999) Nutrient cycling and plant dynamics in estuaries: a brief review. Acta Oecol 20:237-248

> Gao YN, Liu BY, Xu D, Zhou QH and others (2011) Phenolic compounds exuded from two submerged freshwater macrophytes and their allelopathic effects on Microcystis aeruginosa. Pol J Environ Stud 20:1153-1159

> Glomski LM, Wood KV, Nicholson RL, Lembi CA (2002) The search for exudates from Eurasian watermilfoil and Hydrilla. J Aquat Plant Manag 40:17-22

> Godshalk GL, Wetzel RG (1978) Decomposition of aquatic angiosperms. I. Dissolved components. Aquat Bot 5: 281-300

$>\mathrm{Gu}$ B (2006) Environmental conditions and phosphorus removal in Florida lakes and wetlands inhabited by Hydrilla verticillata (Royle): implications for invasive species management. Biol Invasions 8:1569-1578

> Havens KE (2003) Submerged aquatic vegetation correlations with depth and light attenuating materials in a shallow subtropical lake. Hydrobiologia 493:173-186

> Hedges JI, Stern JH (1984) Carbon and nitrogen determinations of carbonate containing solids. Limnol Oceanogr 29:657-663

> Hooper DU, Vitousek PM (1998) Effects of plant composition and diversity on nutrient cycling. Ecol Monogr 68: 121-149

Hung CC, Santschi PH (2001) Spectrophotometric determination of total uronic acids in seawater using cationexchange separation and pre-concentration by lyophilization. Anal Chim Acta 427:111-117

> Hung CC, Warnken KW, Santschi PH (2005) A seasonal survey of carbohydrates and uronic acids in the Trinity River, Texas. Org Geochem 36:463-474 
Kowalczuk P, Cooper WJ, Whitehead RF, Durako MJ, Sheldon W (2003) Characterization of CDOM in an organicrich river and surrounding coastal ocean in the South Atlantic Bight. Aquat Sci 65:384-401

Kuipers B, van Noort GJ, Vosjan J, Herndl GJ (2000) Diel periodicity of bacterioplankton in the euphotic zone of the subtropical Atlantic Ocean. Mar Ecol Prog Ser 201: $13-25$

Madsen JD, Chambers PA, James WF, Koch EW, Westlake DF (2001) The interaction between water movement, sediment dynamics and submersed macrophytes. Hydrobiologia 444:71-84

Maie N, Jaffé R, Miyoshi T, Childers DL (2006) Quantitative and qualitative aspects of dissolved organic carbon leached from senescent plants in an oligotrophic wetland. Biogeochemistry 78:285-314

Mann CJ, Wetzel RG (1996) Loading and utilization of dissolved organic carbon from emergent macrophytes. Aquat Bot 53:61-72

McEntire JM (2009) The sources and cycling of nutrients and dissolved organic carbon in the lower ACF basin and Lake Seminole. MSc thesis, University of Georgia, Athens, GA

Nunnery JK, Mevers E, Gerwick WH (2010) Biologically active secondary metabolites from marine cyanobacteria. Curr Opin Biotechnol 21:787-793

Ogawa H, Amagai Y, Koike I, Kaiser K, Benner R (2001) Production of refractory dissolved organic matter by bacteria. Science 292:917-920

Opsahl SP (2005) Organic carbon composition and oxygen metabolism across a gradient of seasonally inundated limesink and riparian wetlands in the southeast coastal plain. Biogeochemistry 76:47-68

Opsahl SP, Benner R (1999) Characterization of carbohydrates during early diagenesis of five vascular plant tissues. Org Geochem 30:83-94

Paerl HW, Huisman J (2009) Climate change: a catalyst for global expansion of harmful cyanobacterial blooms. Environ Microbiol Rep 1:27-37

Phlips EJ, Ihnat J, Conroy M (1992) Nitrogen fixation by the benthic freshwater cyanobacterium Lyngbya wollei. Hydrobiologia 234:59-64

Pomeroy LR, Sheldon JE, Sheldon WM (1994) Changes in bacterial numbers and leucine assimilation during estimations of microbial respiratory rates in seawater by the precision Winkler method. Appl Environ Microbiol 60: 328-332

Sammons SM, Maceina MJ, Partridge DG (2005) Population characteristics of largemouth bass associated with changes

Editorial responsibility: Craig Carlson,

Santa Barbara, California, USA in abundance of submersed aquatic vegetation in Lake Seminole, Georgia. J Aquat Plant Manag 43:9-16

Scheffer M, Hosper SH, Meijer ML, Moss B, Jeppesen E (1993) Alternative equilibria in shallow lakes. Trends Ecol Evol 8:275-279

Schindler DW (2009) Lakes as sentinels and integrators for the effects of climate change on watersheds, airsheds, and landscapes. Limnol Oceanogr 54:2349-2358

Shivers SD (2010) The impact of submerged aquatic vegetation on nutrient dynamics and bacterial metabolism in a southeastern reservoir. MSc thesis, University of Georgia, Athens, GA

Smart MR, Barko JW (1985) Laboratory culture of submersed freshwater macrophytes on natural sediments. Aquat Bot 21:251-263

Stepanauskas R, Farjalla VF, Tranvik LJ, Svensson JM, Esteves FA, Granéli W (2000) Bioavailability and sources of DOC and DON in macrophyte stands of a tropical coastal lake. Hydrobiologia 436:241-248

Takamura N, Kadono Y, Fukushima M, Nakagawa M, Kim BO (2003) Effects of aquatic macrophytes on water quality and phytoplankton communities in shallow lakes. Ecol Res 18:381-395

Torak LJ, Crilley DM, Painter JA (2006) Physical and hydrochemical evidence of lake leakage near Jim Woodruff Lock and Dam and ground-water inflow to Lake Seminole, and an assessment of karst features in and near the lake, southwestern Georgia and northwestern Florida. USGS Scientific Investigations Report 2005-5084. USGS, Reston, VA

Tranvik LJ, Downing JA, Cotner JB, Loiselle SA and others (2009) Lakes and reservoirs as regulators of carbon cycling and climate. Limnol Oceanogr 54:2298-2314

Wang HQ, Cheng SP, Zhang SH, He F and others (2010) Chemical composition in aqueous extracts of Potamogeton malaianus and Potamogeton maackianus and their allelopathic effects on Microcystis aeruginosa. Pol J Environ Stud 19:213-218

Wang H, Liang F, Zhang L (2015) Composition and anticyanobacterial activity of essential oils from six different submerged macrophytes. Pol J Environ Stud 24:333-338

> Wang L, Priscu JC (1994) Stimulation of aquatic bacterial activity by cyanobacteria. Hydrobiologia 277:145-158

Wilkinson JF (1963) Carbon and energy storage in bacteria. J Gen Microbiol 32:171-176

> Williamson CE, Dodds W, Kratz TK, Palmer MA (2008) Lakes and streams as sentinels of environmental change in terrestrial and atmospheric processes. Front Ecol Environ 6:247-254

Submitted: November 22, 2013; Accepted: January 2, 2016 Proofs received from author(s): February 15, 2016 